\title{
NĚKTERÁ SPECIFIKA VNÍMÁNÍ INTERPRETAČNÍCH SOUTĚŽÍ Z POHLEDU ŽÁKŮ A STUDENTŮ ZÁKLADNÍCH A STŘEDNÍCH HUDEBNÍCH ŠKOL
}

Existence ZUŠ (základních uměleckých škol) v našem vzdělávacím systému přináší nepochybně komfort v práci s nadanými dětmi. Finanční podpora, která se tomuto vzdělávání dostává ze strany státu, a to nejen pro školy jím zrrizované, ale za určitých podmínek i pro školy soukromé (SZUŠ), umožňuje dětem pracovat pod vedením kvalifikovaných pedagogů a rozvíjet své nadání v podmínkách, které by jim jejich rodiče bez zmíněných dotací stěží mohli dopřát. ${ }^{1}$

Kromě podpory samotného studia jsou každoročně realizovány také soutěže, vypisované vždy pro několik vybraných oborů, v nichž mají děti možnost prostřednictvím školních, okresních, krajských a celostátního kola tř́ibit své zkušenosti a postupně poznávat další hranice svého talentu. ${ }^{2}$ „První místo s postupem“ se tak stává metou pro mnoho z nich, jsou to otevřené dveře „,do dalšího levelu“3. Kromě soutěží vypisovaných MŠMT jsou k dispozici i soutěže specializované, a to jak vícekolové, tak jen jednokolové, opakující se každoročně a umožňující pravidelnou zpětnou vazbu v průběhu studia dětí. V této studii bude zaměřena pozornost na obor hudební, a to zejména v souvislosti s cíli, které si hudební školy kladou ve vztahu k výchově směřované k profesní dráze hudebníka.

Účast na různých soutěžích během doby studia ZUŠ bývá chápána jako důležitá zkušenost již pro nejmladší hudebníky. Mají možnost nejen porovnat své výkony s ostatními dětmi, stejně starými a podobně nadanými, ale i navázat s nimi

1 Vyhláška č. 71/2005 Sb., o základním uměleckém vzdělávání. In: Zákony V/2009: Sborník úplných znění zákonů pro státní správu, veřejnou správu a školství. Český Těšín: Poradce, 2009.

Ministerstvo školství, mládeže a tělovýchovy: Základní umělecké vzdělávání [online]. [Cit. 2015-11-1]. Dostupné z: <http://www.msmt.cz/vzdelavani/zakladni-vzdelavani/zakladni-umelecke-vzdelavani>.

Bodové hodnocení není jedinou možností v hodnocení soutěží ZUŠ, v praxi těchto soutěží ovšem převládá. Organizační řád i manuál hodnocení přinášejí webové stránky Ústřední umělecké rady ZUŠ:

Organizační ŕád soutěži a prehlídek ZUŠ. Manuál hodnocení [online]. [Cit. 2015-11-1]. Dostupné z: <http://www.uur-zuscr.cz/dokumenty/organizacni-rad>. 
kontakt, poslechnout si řadu skladeb, které později sami hrají a v neposlední řadě posilovat svoji schopnost vypořádat se s negativními jevy, spjatými s tímto typem vystupování, tedy s problémy načasování výkonu, s trémou apod.

Pokud uspějí, získají v podobě výsledného umístění či zpětné vazby výkonu od poroty kromě rostoucí pozitivní motivace $\mathrm{k}$ soutěžení také důležitou položku do svého „profesního životopisu“. Podařený výkon pak s sebou nese další chut' ve hře na nástroj pokračovat a věnovat jí čas a pozornost. V př́ípadě volby hudební profese pak otevírá cestu $\mathrm{k}$ úspěšnosti při přijímacích zkouškách na specializované střední hudební školy, jako jsou konzervatoře či (zejména některá) hudební gymnázia.

Úvahy, zda je účast na soutěžích, v té podobě, ve které dnes existují, kladem nebo záporem ve vztahu k maximálnímu a současně ideálně nastavenému rozvoji hudebního nadání dětí, provázejí v různých intenzitách tento jev jak mezi dětmi samotnými, tak mezi jejich rodiči a pedagogy.

Náhled dětí je bezpochyby podmíněn úrovní a typem motivace ze strany okolí, tedy především ze strany rodiny a pedagoga, a liší se zejména $\mathrm{v}$ závislosti na věku, ve kterém dítě tuto zkušenost nabývá. U nejmenších lze vysledovat často nadšení ze samotné hry, radost $\mathrm{z}$ toho, že mohou předvést ostatním, co už umí, s přibývajícím věkem a zkušenostmi však často přichází navíc i obava, aby se výkon podařil, jak má, a aby byl dostatečně dobrý i pro ono okolí - soutěžní porotu, pedagogy a rodinu. Dochází tu tedy zejména v sólových soutěžích $\mathrm{k}$ vypořádání se nejen se skladbami jako takovými (jak po technické, tak i muzikantské stránce), ale i se sebou samým a schopností soustředěného výkonu navzdory trémě, která výkon více či méně doprovází, a taktéž s očekáváním okolí, nejvíce viditelným $\mathrm{v}$ bezprostřední reakci na daný výkon.

Pohled rodičủ (a potažmo rodiny jako takové) souvisí s jejich vnímáním dané situace. Považují-li soutěžní prostředí za zátěžové, velmi těžko se také dítě této představy zbavuje. Mají-li však společné ambice s dítětem, mohou mu ulehčit situaci přinejmenším v tom směru, že z jejich strany dítě cítí podporu a méně řeší i př́padnou nepř́liš pozitivní zpětnou vazbu od pedagoga či hodnotící poroty.

Stanovisko pedagogů je ovlivněné skutečností, že každá zkušenost před publikem dítě posunuje ke kvalitnějšímu výsledku. Toto je fakt zaznamenatelný již na třídních přehrávkách škol, kde „o nic nejde“, a přesto se i rozpracované verze skladby často značně vylepší, protože dítě „zmobilizuje síly“ k co nejlepšímu prredvedení. Na druhé straně je nutné zmínit, že pro pedagoga ZUŠ právě úspěšnost dětí v soutěžích znamená nejen profesní prestiž, ale i finanční ohodnocení ze strany zaměstnavatele a taktéž důležitou položku v jeho profesním životopisu, což, zůstane-li účast dítěte v soutěži postavená pouze na těchto motivačních zdrojích, může vést $\mathrm{k}$ počátku rozkolů $\mathrm{v}$ tandemu žák-učitel-rodič. Tento druh motivace je však do určité míry nastaven již základním očekáváním ze strany zřizovatelů ZUŠ, které stanovuje hodnocení úrovně školy také podle počtu a prestiže získaných ocenění na soutěžích, at' už tuzemských či zahraničních.

Tato studie vychází z dotazníkových šetření uskutečněných $\mathrm{v}$ průběhu roku 2014, jejichž vyhodnocení mělo za cíl zmapovat pomocí kvantitativního př́stupu jevy související s přípravou žáků a studentů hudebních škol na profesní dráhu 
hudebníka či hudebního pedagoga a stalo se základem pro disertační práci Průběh prípravy na profesní dráhu hudebnika a motivace k profesi z pohledu žáki̊ a studentů uměleckých škol obhájenou v roce 2015.

Na vzorku žáků ZUŠ účastnících se okresních a krajských kol interpretačních soutěží ZUŠ v oborech smyčcové nástroje, klavír, kytara a soutěží dechových souborů a orchestrů, a rovněž účastníků dvou nezávislých soutěží určených oboru zobcové a zobcové a př́čné flétny - Teplické flautohry a Novohradská flétna (celkový vzorek dosáhl počtu 922 navrácených dotazníků), bylo možné mimo jiné sledovat rodinné zázemí a soutěžní minulost jak dětí účastnících se sólových výkonů (489 dotazníků), tak i těch, které se prezentovaly v rámci souborové hry (415 dotazníků), eliminující problémy individuální trémy, nebo se zúčastnily obou typů soutěže (18 dotazníků).

Lze tedy odpovědět na některé otázky specifikující vzorek dětí, které jsou obdařeny určitým stupněm talentu a který potenciálně zahrnuje jak budoucí hudební amatéry, tak i profesionály, tedy jinak řečeno budoucí studenty středních hudebněuměleckých škol. Primární zájem vedl především ke zjištění, jak velká část $\mathrm{z}$ nich pochází z rodin s rodiči věnujícími se hudbě profesně (hudebníci a hudební pedagogové), tedy zda se soutěžní koloběh do určité míry nestává jednostrannou záležitostí pouze dětí z profesních rodin, u nichž lze předpokládat specifickou př́pravu, a tím i větší šance na úspěch.

Pokud by se takový jev prokázal, ukazoval by přinejmenším na latentní potřebu i jiného zapojení ostatních hudebně nadaných dětí, kterou by bylo možno v budoucnosti realizovat např. ve formě dalších doplňujících projektů, při nichž by kritéria byla postavena na odlišných parametrech než „pouze“ na dokonalosti technického ovládnutí vlastního nástroje prezentované předem nastudovanými skladbami. Těmto dalším možnostem obohacení rozvoje talentu dětí hudebních škol se bude věnovat závěr textu.

Vzorek studentů středních a vysokých hudebních škol přinesl data 516 dotazníků studentů konzervatoří (Praha, Brno, Ostrava, České Budějovice, Pardubice, Kroměřǐž, Olomouc), 119 dotazníků studentů hudebních gymnázií (Praha, Ostrava) a 57 dotazníků studentů vysokých hudebních škol (AMU Praha, JAMU Brno). Výsledky kvantitativního vyhodnocení dat obou typů středních škol lze tedy (a to i z důvodu reprezentativnosti po stránce rozložení jednotlivých hudebních oborů), minimálně do určité míry, zobecňovat. U vysoké školy mohou sloužit pouze jako naznačení či ukazatel určitých jevů nutných k ověření dalším výzkumem.

Otázky zde byly zaměřeny primárně na význam soutěžních zkušeností ve vztahu k profesnímu vývoji, tedy především na četnost účasti v soutěžích během studia nástroje před vstupem na střední školu, motivaci tohoto kroku (zda byla vyvolána zájmem žáka samotného, učitelem či rodinou) vnímání náročnosti, ale také zhodnocení pozitiv a negativ, která $\mathrm{v}$ účasti na soutěžích studenti zpětně viděli. Také tady byla věnována pozornost odlišnosti odpovědí podle zázemí, ze kterého student pochází. Tato data tedy mohou zpětně vypovídat o vnímání důležitosti a adekvátnosti existence soutěží ve stávající podobě, a to pro vzorek těch, kteří se připravují na budoucí hudební profesi. 


\section{Vyhodnocení dat žáků ZUŠ}

Na stěžejní otázku, zda se zejména sólové soutěže netýkají především žáků z rodin s profesním hudebním zázemím, lze jednoznačně odpovědět, že nikoli. Jejich celkový počet tvořil v sebraném vzorku pouze $8,5 \%$ (jde o součet př́padů, v nichž žák uvedl profesi hudebníka či hudebního pedagoga alespoň u jednoho z rodičů). Nejvyšší zastoupení představuje v součtu trojice kategorií rodin, v nichž alespoň jeden z rodičů (matka, otec nebo oba) hrál nebo hraje na nějaký hudební nástroj, ovšem nikoli profesně. Sem spadá celkem 62,6 \% odpovědí. Na rozdíl od vzorku studentů konzervatoře, zde nelze blíže rozlišit typ hudebního vzdělání, celkový počet zahrnuje tedy jak rodiče samouky, tak ty, kteří prošli formou výuky v hudebních školách nebo se učili na nástroj soukromě.

Bližší pohled ukazuje rozlišení mezi rodinami, v nichž hraje na nástroj pouze matka, pouze otec či oba rodiče. Poměr těchto skupin je 24,9 \%-18,2 \%-19,5\%. Podobný poměr - převládající počet rodin $\mathrm{s}$ hudebně aktivními matkami - lze vidět i ve skupině rodin s rodiči v hudební či hudebně pedagogické profesi. Zde tvoř́ 3,9 \%-1,8 \%-2,8 \%. Do rodin, v nichž ani jeden z rodičů nikdy na nástroj nehrál, spadá $28,8 \%$ př́padů odpovědí.

$\mathrm{Z}$ hlediska spektra hudebních nástrojů bylo zajímavé sledovat, zda se objevují všechny nástroje ve stejné míře ve všech kategoriích hudebního zázemí rodiny, zda nevykazují výjimečně vysoké hodnoty pouze v některých z nich, a také, zda jsou nástroje zastoupeny ve stejné míře $\mathrm{v}$ kategoriích rodin $\mathrm{s}$ rodiči v profesi.

Pro porovnání dat $\mathrm{s}$ ohledem na hudebního zázemí připojme alespoň aktualizovanou tabulku nejčetněji zastoupených oborů, ovšem s upřesněním, že zde chybí obory v sebraném vzorku žáků ZUŠ víceméně absentující, tedy keyboard, akordeon a zpěv. Ve vztahu k rodinám s profesí hudebníka či hudebního pedagoga alespoň u jednoho z rodičủ je třeba ř́íci, že zcela chybělo zastoupení hoboje, fagotu, tuby, violy a kontrabasu.

\begin{tabular}{|c|c|c|c|c|c|c|c|}
\hline & $\begin{array}{c}\text { Bez hudební- } \\
\text { ho nástroje }\end{array}$ & $\begin{array}{c}\text { Hudební ná- } \\
\text { stroj matka }\end{array}$ & $\begin{array}{c}\text { Hudební } \\
\text { nástroj otec }\end{array}$ & $\begin{array}{c}\text { Hudební } \\
\text { nástroj oba } \\
\text { rodiče }\end{array}$ & $\begin{array}{c}\text { Profese } \\
\text { matka }\end{array}$ & $\begin{array}{c}\text { Profese otec } \\
\text { Oba rodiče } \\
\text { profese }\end{array}$ \\
\hline 1. & Klavír & Klavír & Klavír & Klavír & Housle & Klavír & Klavír \\
& 13,6 & 22,3 & 20,3 & 26,3 & 22,2 & 23,5 & 46,2 \\
\hline 2. & Zobcová fl. & Housle & Housle & Housle & Klavír & Housle & Kytara \\
& 12,8 & 18,8 & 13,7 & 15,6 & 22,2 & 17,6 & 11,5 \\
\hline 3. & Kytara & Kytara & Zobcová fl. & Kytara & Zobcová fl. & Kytara & Housle \\
& 12,5 & 13,5 & 10,7 & 12,8 & 13,9 & 17,6 & 7,7 \\
\hline 4. & Housle & Zobcová fl. & Trubka & Trubka & Kytara & Bicí & Violoncello \\
& 12,1 & 11,4 & 7,9 & 10,6 & 8,3 & 11,8 & 7,7 \\
\hline 5. & Klarinet & Trubka & Kytara & Zobcová fl. & Violoncello & Trombon & Zobcová fl. \\
& 10,2 & 10,1 & 7,7 & 10,1 & 5,6 & 5,9 & 7,7 \\
\hline
\end{tabular}

Tab. 1. ZUŠ - Nejčastěji zastoupené nástroje žáků (v \% k Hudební zázemí v rodině) 
Vrátíme-li se však k rozdílům v zapojování žáků do soutěží sólových a orchestrálních, následující graf demonstruje, nakolik se děti z jednotlivých typů hudebního zázemí objevovaly v obou těchto skupinách. Vidíme, že přednost soutěžení $\mathrm{v}$ orchestrální či komorní hře dávají logicky děti z rodin rodičů bez nástrojů a rodin, v nichž hraje na nástroj otec, a to i v profesních i neprofesních rodinách. Také se ukazuje, že pokud děti z profesních rodin absolvovaly soutěžní vystoupení sólové, neúčastnily se již v rámci stejné soutěže rovněž kategorie komorní hry.

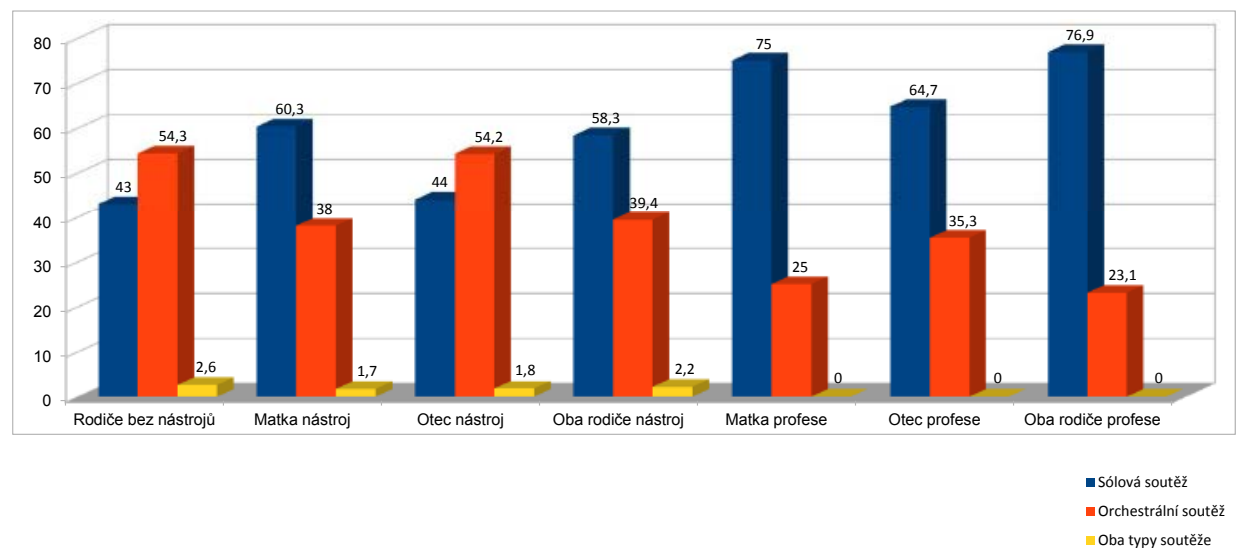

Tab. 2. ZUŠ - Zastoupení v jednotlivých typech soutěži (v \% k Hudební zázemí v rodině).

Na druhou stranu lze konstatovat, že zapojování dětí do soutěží sólových a soutěží komorních souborů a orchestrů není dvěma samostatnými světy. Všichni hráči v soutěžích souborů a orchestrů zodpovídali otázku, zda se již v minulosti zúčastnili rovněž sólových soutěží ve svých oborech. Výsledky dokládají, že téměř $51 \%$ z nich má za sebou zkušenost sólové soutěže s nástrojem, na který hraje v souboru, další $2 \% \mathrm{~s}$ dalším paralelně studovaným nástrojem a 2,5\% se dvěma a více různými nástroji. Navíc u některých dalších lze podobnou zkušenost teprve očekávat vzhledem $\mathrm{k}$ jejich nízkému věku.

Další nikoli nepodstatnou otázkou vztahující se k praxi soutěží je, zda žáci navštěvují soutěže opakovaně či pro ně soutěžní zkušenost znamená zážitek, který dále nevyhledávají. Proto bylo zajímavé porovnat výsledky obou skupin žáků (tedy účastníků pouze sólových a pouze orchestrálních soutěží) s pomocí otázky „Účastnil ses už někdy dřive sólové soutěže pro Tvưj nástroj? “. Logicky není možné dozvědět se zpětnou vazbu od těch, kteří zaznamenali v minulosti na soutěžích negativní zážitky, a nyní z vlastního rozhodnutí ve spektru soutěžících chybí. Bylo však možné podívat se na stávající data a konstatovat, jak velký počet dětí dosud uspěl např̀. jen ve školních kolech soutěže, nebo nezískal výraznější ocenění, a přesto se znovu soutěže účastní apod. Jako druhotný zdroj informací mohou sloužit soutěžní rozpisy v jednotlivých kategoriích a oborech, které počtem žáků v jednotlivých kategoriích naznačují chut' zabývat se soutěžením i ve vyšším věku. 
V sólových soutěžích zaživalo soutěžní zkušenost opakovaně 50,4 \% zúčastněných žáků, pro $48,8 \%$ to byla první zkušenost se sólovou soutěží, $0,8 \%$ se již účastnilo soutěže, ovšem v jiném oboru. U žáků orchestrálních a souborových soutěží není možné rozhodnout, zda se v budoucnu budou vracet ke zkušenosti sólové soutěže, žádnou takovou však dosud neabsolvovalo, jak už bylo řečeno, jen $44 \%$ z nich.

Důležitým ukazatelem pro bližší pochopení kategorie předchozí neúčasti v sólové soutěži je rovněž věk účastníků. Zcela logicky sem jsou vřazeni všichni nejmladší účastníci, jimž logicky chyběla možnost zažít soutěž opakovaně, a u kterých také nelze s jistotou ríci, zda budou danou zkušenost $\mathrm{v}$ budoucnu vyhledávat. Lze vysledovat, že přelom v opakovaném zapojení do soutěží činí věk 10 a 11 let. Zatímco od 6 do 10 let věku se pohybuje křivka ze $100 \% \mathrm{k} 65,6 \%$ předchozí neúčasti pozvolna, u věku 11 let lze pozorovat rázem pouze 35,3\% takových př́padů a tato hodnota tvoří průměr hodnot až ke skupině čtrnáctiletých.

$\mathrm{Na}$ otázku opakovaných účastí nakonec daleko nejpřesněji odpovídá náhled do rozpisů soutěží. U všech oborů víceméně zaznamenáváme postupný úbytek přihlášených účastníků v souvislosti se stoupajícím věkem a tedy i přechodem do vyšších kategorií. Zatímco nejmladší jsou zastoupeni často v řádu desítek (ostatně nultá kategorie shrnuje širší věkové zastoupení), u vyšších kategorií odpovídající věku zejména 12-14 let, bývá počet přihlášených často i pouhých několik jedinců $v$ jedné kategorii (viz např. okresní kolo houslové soutěže Brno-město). Teprve kategorie odpovídající 2. cyklu ZUŠ pak přinášejí opět zvýšení počtu účastníkủ. Úbytek $\mathrm{s}$ věkem souvisí se stupňováním nároků na repertoár očekávaný ze strany odborné poroty pro jednotlivé kategorie, zájem u středoškoláků pak ukazuje na skupinu těch, kteří byli ve svém oboru dobř́í, avšak nezvolili (nebo z jakéhokoli důvodu nestačili na) cestu studia na konzervatoři.

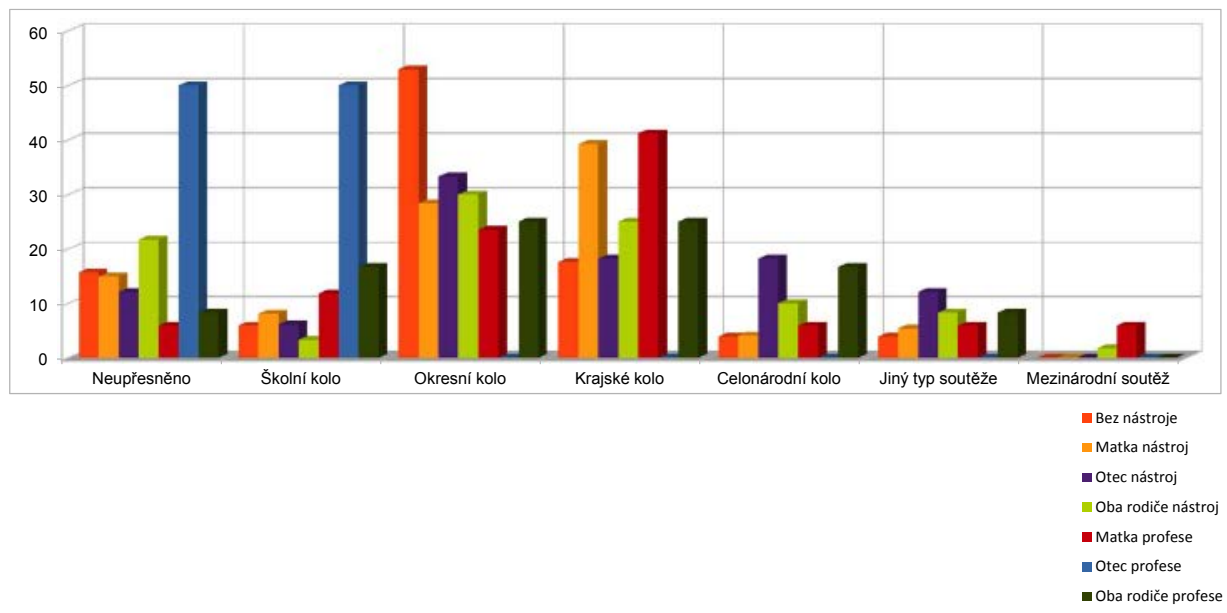

Tab. 3. Opakovaná úspěšnost v individuálních soutěžích u žáků účastnících se individuálních soutěží ( $\mathrm{v} \% \mathrm{k}$ Hudební zázemí v rodině). 
Závěrem je vhodné ještě ukázat poměr úspěšnosti, co se týká dosud získaných ocenění v sólových soutěžích, a to v obou skupinách - dětí účastnících se individuálních soutěží a dětí ze soutěží orchestrů a komorní hry. Vztah k hudebnímu zázemí ukazuje na skutečnost výrazného vlivu rodičů $\mathrm{v}$ profesi pro úspěšnost v soutěžích tohoto typu, ovšem s konstatováním, že děti otců v profesi s vyšším umístěním dávaly pravděpodobně daleko častěji přednost soutěžím druhého typu (tvrzení stojí a padá $\mathrm{s}$ vysokým počtem neupřsněných ocenění u dětí z těchto rodin $\mathrm{v}$ individuálních soutěžích).

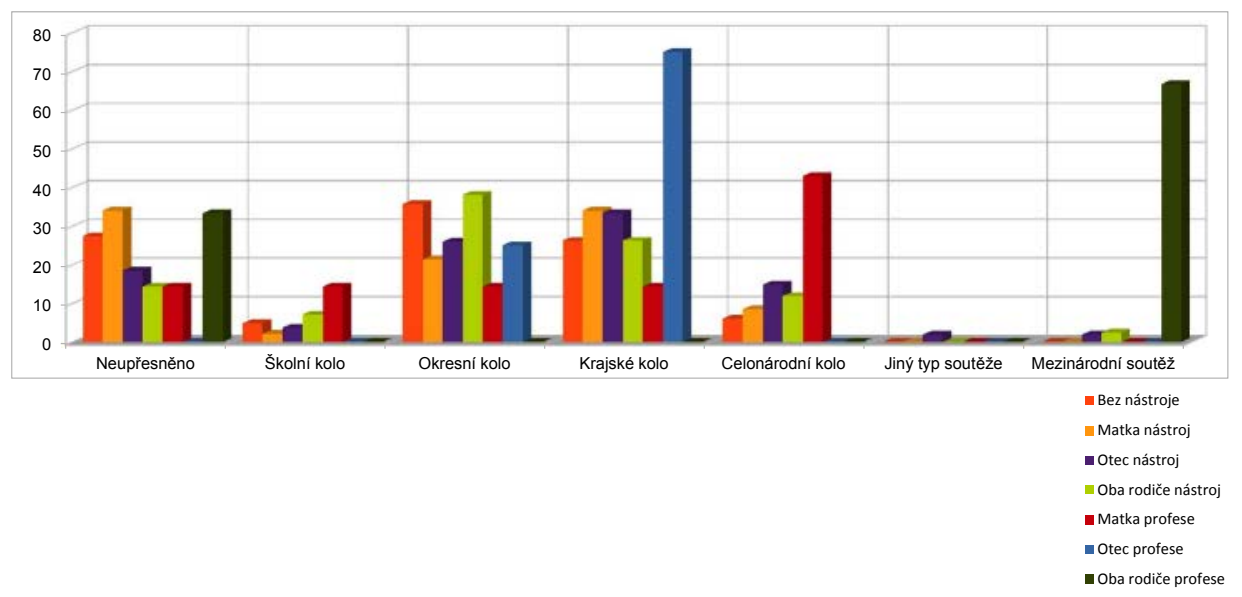

Tab. 4. Úspěšnost v individuálních soutěžích u žáků účastnících se orchestrálních a komorních soutěží (v \% k Hudební zázemí v rodině)

Vzhledem $\mathrm{k}$ počtu neupřesněných odpovědí (šlo o prŕípady, kdy dítě vypsalo, že napřr. získalo v minulosti 2 . místo, ale neupřesnilo, v jakém kole soutěže) nelze přesně zhodnotit rozdíly $\mathrm{v}$ obou skupinách, přesto se zdá evidentní, že se sólovým soutěžím věnuje opětovně nezanedbatelné množství těch, kteří v nich v minulosti uspěli. Potěšitelné je, že jsou taktéž součástí orchestrálních a komorních seskupení, že tedy (lze to konstatovat minimálně u dechových nástrojü, kterým v daném roce výzkumu byly soutěže orchestrů určeny a jejichž zastoupení ve vzorku převládalo) nedochází $\mathrm{k}$ tomu, že by se zkušenosti souborové hry vyhýbali a specializovali se pouze na sólovou př́ípravu. Podpoře tohoto jevu ostatně napomáhá i fakt, že se v harmonogramu soutěží ZUŠ soutěže orchestrů a souborů záměrně vypisují v jiné roky než soutěž týchž oborů v sólové hře.

\section{Vyhodnocení dat studentů konzervatoře}

U studentů konzervatoře se skrytě očekává, že v okamžiku nástupu na školu již budou mít za sebou řadu soutěžních úspěchů. $O$ jak velký počet $\mathrm{z}$ celkového množství studujících jde, ukazují v kostce následující výsledky. Celých 83,1\% 
sebraných odpovědí vykazuje alespoň jednu soutěžní zkušenost studenta ve svém nyní studovaném oboru, zbývajících 16,9 \% žádnou takovou soutěžní zkušenost nepodstoupilo. V této souvislosti je sice nutné podotknout, že nedostáváme odpověd' na otázku, zda se tito studenti nezúčastnili soutěže $\mathrm{v}$ jiném $\mathrm{z}$ dř́ve studovaných nástrojü ${ }^{4}$, avšak konstatování faktu, že absence soutěžní zkušenosti není nepřekonatelnou překážkou pro přijetí na střední školu tohoto typu, je rovněž důležitým poznatkem. Vyšší počet kladných odpovědí v prrípadě účasti na soutěžích je zaznamenán mezi dívkami (85 \%), u chlapců byl mírně nižší $(79,7$ \%).

$\mathrm{Z}$ odpovědí $\mathrm{v}$ rámci jednotlivých studijních oborů jsou zejména zajímavé př́ipady uvedení $100 \%$ účasti v soutěžích. Zde lze jmenovat hned několik takových oborů, a to klarinet, fagot, saxofon, cimbál, akordeon a dirigování. Důležité je zdůraznit, že otázka byla směrována přímo na sólovou soutěžní zkušenost, nevztahuje se tedy $\mathrm{k}$ účasti v soutěžích komorní hry ani hry v rámci žákovských souborů a orchestrů. Zároveň je třeba uvést, že zastoupení těchto oborů v celkovém vzorku konzervatoře představovaly často podstatně nižší počty jedinců než početně preferované studijní obory typu klavír, smyčcové nástroje, zpěv.

U nižší hodnoty účasti $\mathrm{v}$ soutěžích $\mathrm{v}$ př́ípadě některých $\mathrm{z}$ oborů může být vysvětlením jevu také fakt, že se studenti k jejich studiu dostávají teprve v pozdějším věku nebo dokonce až s nástupem na konzervatoř (případ přechodu na př́íbuzný obor nabídnutý školou v případě neúspěšných přijímacích zkoušek $\mathrm{v}$ oboru stávajícím sledovatelný např. u houslí-violy, violoncella-kontrabasu, klavíru-varhan, flétny, klarinetu-fagotu apod.).

Následující graf tedy přináší přehled, kolik \% studentů konzervatoře mělo před nástupem na tuto školu zkušenost se soutěží v oboru, který nyní studuje.

Z hlediska zázemí rodiny je $\mathrm{v}$ získaných datech jasně patrná větší četnost př́ípadů účasti na soutěžích u rodin více spjatých s hudbou. Zatímco v rodinách rodičů nemajících za sebou zkušenost se studiem hudebního nástroje (tato skupina pracovně nazývaná Rodiče bez nástroje ovšem zahrnuje určité \% samouků) se soutěží účastnilo jen $77,5 \%$, u rodin se zkušeností alespoň jednoho z rodičů se studiem nástroje na ZUŠ se již pohybují jen s rozdílem několika desetin na hladině $85,5 \%$, a výsledky studentů $\mathrm{z}$ rodin s rodiči v profesi (at' už hudební či hudebně-pedagogické) dosahují až na 86-91\%. Nejvyšší počet 91,3 \% je zaznamenán u dětí z rodin matek v profesi, ve vyhodnocení dalších otázek se ukazovala jako výrazná zejména vazba této kategorie na obory klavír a smyčcové nástroje (housle, viola, kontrabas) ${ }^{5}$.

$4 \quad$ Získaná data ukazovala velmi pestrou nástrojovou minulost u značné části studentů nejen tohoto typu střední hudební školy, a to jak ve vztahu k počtu ovládnutých nástrojů (pouze na jeden nástroj se učilo před dobou nástupu na konzervatoř $32 \%$ studentů, na 2 nástroje pak $40 \%$, na 3 nástroje $20 \%$, počet čtyř a více nástrojů zahrnoval $7 \%$ odpovědí, započítávány nebyly nástroje ovládnuté formou samostudia), tak k faktu, jakým typem hudebního školení v něm student prošel a či volil nástroj nejdéle studovaný nebo absolvoval účelovou změnu oboru ve vyšším věku např. kvůli zvýšení šancí na přijetí na tuto školu.

5 Viola jako studovaný nástroj dítěte je právě v kategorii Matek v profesi uvedena v nejvyšším počtu procent $(13,5 \%)$ vůči pracovní kategorii Hudebnost rodiny, která byla, jak už bylo ře- 


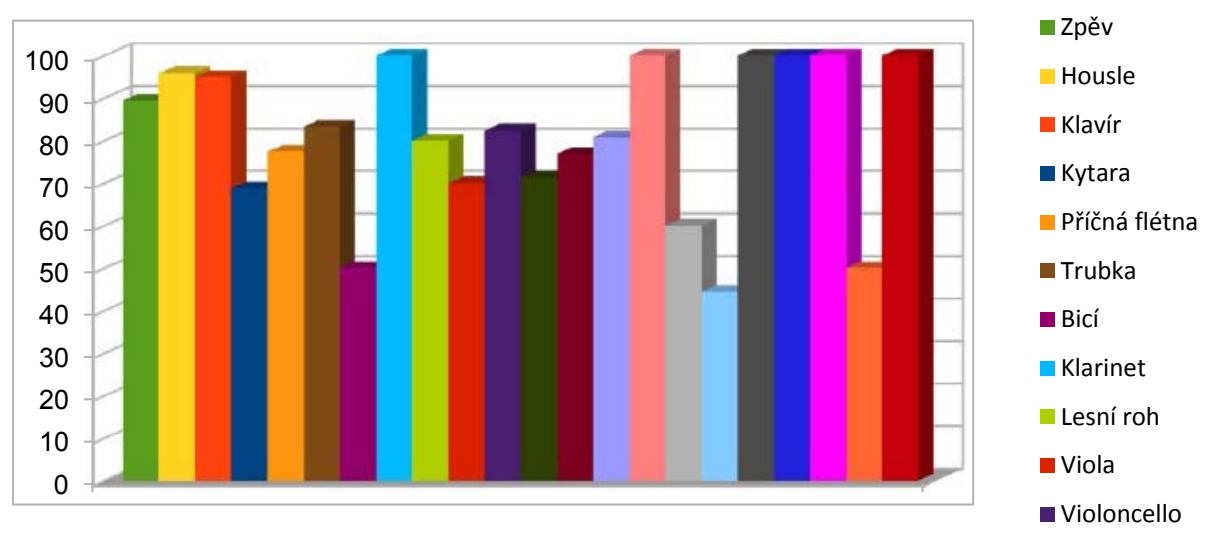

Tab. 5. Konzervatoř - Zkušenost studenti̊ se soutěžemi během studia ZUŠ (v platných \%).

Co do četnosti soutěžních zkušeností ukazují data, že nejběžnější variantou byla účast méně často než jedenkrát ročně. (Na otázku „Jak často jste se zúčastňoval/a sólových soutěži " mohli studenti vybrat odpověd' ze tří nabízených variant Několikrát ročně - Jednou za rok-Méně často). Zde bylo zaznamenáno 45,5\% př́ípadů, varianta jednou za rok byla zvolena v 27,4 \% a několikrát ročně v 26,7 \%. Zejména takto vysoké číslo u třetí jmenované kategorie (u více než čtvrtiny studentů) nebylo očekáváno (i když v praxi jde většinou o jeden nastudovaný repertoár, který je předveden během roku na několika soutěžích). První z kategorií byla shodně zastoupena chlapci i dívkami, ve druhé šlo častěji o př́pady chlapců, abnormální soutěžní zatížení pak podstupovaly častěji dívky $(29,7 \%)$ než chlapci $(21,2 \%)$. Z konkrétních oborů byly v nejvyšší kategorii nejčastěji zahrnuti zpěváci (45,3 \%) a hráči na violoncello (42,9 \%). Tradiční soutěžní obory (housle, klavír, kytara), vykazovaly $25-30 \%$. Lze také připojit, že nejčastěji šlo o mnohonásobnou účast za rok u kytar, klavír a housle vykazují největší tendenci k soutěžení méně často než jedenkrát za rok (shodně u obou oborů $50 \%$ zastoupení).

Pokud se podíváme na data četnosti soutěžních vystoupení z pohledu hudebního zázemí rodin, očekávatelný odlišný režim dětí z rodin hudebníků v profesi není jednoznačným jevem. Velmi se odlišují výsledky dětí z rodin matek a obou rodičů $\mathrm{v}$ profesi od dětí $\mathrm{z}$ rodin otců $\mathrm{v}$ profesi. Zatímco první dvě skupiny projevují tendenci k extrémům (nejsilněji jsou zastoupeny kategorie soutěží méně často než jedenkrát za rok a několikrát ročně) $\mathrm{u}$ otců $\mathrm{v}$ profesi se studenti nejčastěji řadí do obou kategorií kladoucích méně nároků. Nejde však o jev související jen s podstatou typu rodiny, spíše o souvislost se specifickým složením mozaiky oborů, které v těchto rodinách děti studují. Je však třeba zdůraznit, že stejný výsledek se ukazoval i u rodin se základním hudebním vzděláním rodičů, také zde

čeno, vytvořena pro potřebu rozlišení hudebního zázemí studentů a v níž dochází k rozřazení do pomocných uměle vytvořených skupin Rodiče bez nástroje-Otec nástroj-Matka nástroj-Oba rodiče nástroj-Otec profese-Matka profese-Oba rodiče profese. 
byly v extrémní skupině soutěží několikrát ročně zaznamenány téměř dvakrát častěji děti z rodin s hudebními zkušenostmi matek a obou rodičů (30 \%) než otců $(17 \%)$. U rodin v profesi je tento jev jen výraznější (u matek a obou rodičů $35 \%$, u otců $15 \%$ ).

Jako doplňující byly připojeny otázky motivace k účasti na soutěžích a hodnocení náročnosti ze strany studenta. Co se týká přesného znění otázek, první byla položena v podobě: Co bylo impulzem k účasti na sólových soutěžich? Rozhodnuti: Vlastní, Rodičù, Pedagogů.

Mezi studenty volícími jen jednu odpověd' převažovalo rozhodnutí pedagoga. Tuto variantu uvedlo $63,5 \%$ z těch, kteří se soutěží zúčastňovali. Vlastní rozhodnutí uvedlo $15,9 \%$ a pouze rozhodnutí rodičů $1 \%$ studenti̊. $Z$ kombinací těchto odpovědí převažovala varianta žák-pedagog (12,7 \%), avšak zejména varianta rodič-pedagog zastoupená $3,4 \%$ odpovědí je zajímavá, protože v sobě může nést stopy nesplněných ambicí.

Moment určitého stupně donucení vysvítá zejména z výsledků chlapců. Jejich zastoupení v kategorii vlastního rozhodnutí je o celých 7 \% nižší než u dívek (mezi chlapci bylo zaznamenáno 11 \% těchto odpovědí), naopak vyšší počet vykazují zejména tam, kde jde o rozhodnutí jiných (u pedagogů i rodičů). Ve výše zmíněné kategorii společného rozhodnutí rodičů a pedagogů převažují tedy podle očekávání z právě prezentovaných dat rovněž odpovědi chlapců $(4,4 \% \mathrm{ku} 1,4 \%$ dívek). Přesto ve vztahu k celkovému vzorku je nutné zdůraznit marginálnost tohoto jevu.

Jako zajímavé se jeví pátrání po prŕćčnách rozdílů $\mathrm{v}$ kategorii typu rodin. Je všeobecně známo, že rodiny s hudebníky v profesi vedou své děti do profese co nejefektivnějším způsobem (včetně zkušeností se soutěžním prostředím). Zde je možné na konkrétních datech tento jev ukázat a porovnat ho s výsledky, které vykazují ostatní typy rodin.

Všeobecně u dětí rodičů v profesi ustupuje zastoupení v kategorii Rozhodnutí pedagoga. U každého z typů rodiny se však tato procenta přelévají do jiných kategorií. Zatímco u dětí matek v profesi je rovněž oslabená kategorie vlastního rozhodnutí a převládají odpovědi společného rozhodnutí dítě-pedagog, dítě-rodič-pedagog (zde šlo dokonce o nejvyšší zastoupení v rámci kategorie dítě-rodič-pedagog, $19 \%$ ), varianta rodič-pedagog vykazuje $9,5 \%$, u dětí otců v profesi se vyčleňují dvě velké skupiny studentů. Jedna, která zastává pozici vlastního rozhodnutí a druhá, stejně velká, uvádějící rozhodnutí tandemu rodiče-pedagog (každá 21,1\%!). V rodinách s oběma rodiči v profesi, s nejslabším zastoupením vlivu pedagogů (jen $31 \%$ ), lze vidět nejvyšší počet př́ípadů vlastního rozhodnutí dítěte $(25 \%)$, doplněné o skupinu rozhodující se v souladu s rodiči či v souladu s pedagogy. Kategorie vynucení rodiči a pedagogy zastává z hlediska výsledků $\mathrm{v}$ rodinách $\mathrm{s}$ rodiči v profesi střední hodnotu $12,5 \%$.

Za zmínku stojí ještě několik podrobností:

1. Kategorie společného rozhodnutí rodičů-pedagogů se s výjimkou jediného prrípadu v rodinách bez hudebního vzdělání (tam činila $0,8 \%$ všech odpovědí) vyskytovala pouze u dětí v rodinách s rodiči v profesi $(88,8 \%)$. 
2. Vzhledem k tomu, že prŕípady společného rozhodnutí dítěte a rodiče spadají pouze do kategorií rodičů $\mathrm{v}$ profesi, bylo nutné ověřit, zda nejde o př́ípady, v nichž je dítě stále vyučováno vlastním rodičem. Ukázalo se, že šlo o děti vyučované v ZUŠ. Děti vyučované vlastními rodiči naopak volily varianty vlastního rozhodnutí nebo kombinace vlastní-pedagog. Tento jev tedy vykazuje značnou úspěšnost v budování pocitu ztotožnění s vlastním profesním směřováním jejich dětí.

3. Nejnižší úroveň vlastního rozhodnutí vykazují děti z rodin s otcem hrajícím na nástroj (jen $11 \%$ ), kompenzováno je výsledky v kategorii rozhodnutí pedagoga, které zde dosahuje vysoké hodnoty 71,4%. (Vyšší byla zaznamenána pouze u dětí rodičů bez hudebního vzdělání $71,9 \%$.)

4. Ačkoli analýza typu vzdělávání před studiem na konzervatoři ukázala, že soukromé vzdělání v celém vzorku studentů konzervatoří tvoří jen 5,4 \%, za zmínku stojí, že ani v jediném př́padě u této vzdělávací formy nebyl zaznamenán prípad rozhodnutí rodič-pedagog, naopak spolu s dětmi vyučovanými rodiči a kombinujícími vzdělání linie samostudium-soukromé vyučování vykazovaly tyto př́ípady nadprůměrné zastoupení $\mathrm{v}$ kategorii vlastního rozhodnutí (u těchto dvou zmíněných kategorií dosahovalo rozhodnutí samotného dítěte dokonce $50 \%$ př́padů!).

Z hlediska hodnocení náročnosti soutěžních zkušeností byla studentům položena otázka: „Náročnost soutěži Vám připadala: Zanedbatelná, Přiměrená, Př́iliš zatěžující." Předpokládá se, že student konzervatoře bude tím dítětem, které se $\mathrm{s}$ nároky soutěžního prostředí dokázalo vypořádat a nebude ho vnímat $\mathrm{v}$ extrému prílišné zátěže. Výsledky s tímto předpokladem korespondují. Variantu přiměřené náročnosti volilo $93,4 \%$ studentů, kteří zkušeností soutěže v dnes studovaném oboru prošli. Jako zanedbatelnou zátěž vnímaly soutěže 3,2 \% studentů, jako príliš zatěžující 3,3\%. Tyto dvě malé skupinky nyní podrobme bližší analýze.

Jak v prrípadě zanedbatelné zátěže, tak u př́lišné převažují dívky, v první skupině je rozdíl nepatrný $(0,3 \%$ ), ve druhé velmi výrazný (u chlapců 2,2 u dívek $4,1 \%) .{ }^{6}$ Kategorie zanedbatelné náročnosti byla zastoupena $v$ mnoha oborech, v několika príípadech i v těch, které jsou jinak vnímány jako velmi náročné (napřr. housle). Ani jedenkrát se však tato odpověd’ neobjevila u oboru klavír. Hodnocení soutěží jako velmi zatěžující zkušenosti se s výjimkou jednoho př́ípadu u lesního rohu neobjevilo ani jedenkrát u žádného z dechových nástrojů. U ostatních oborů se objevily po jednom případě s výjimkou varhan. Nejvíce zatěžujících prípadů shledáváme $\mathrm{v}$ rodinách matek $\mathrm{v}$ profesi $(10 \%)$ a obou rodičů $\mathrm{v}$ profesi (6\%), u otců $\mathrm{v}$ profesi oproti tomu nebyl zaznamenán ani jediný.

U vzorku konzervatoře rozlišme ještě konkrétněji, které jevy studenti hodnotili jako klady a zápory sólové soutěžní praxe $\mathrm{z}$ doby před nástupem na střední školu. Že šlo o otázku pro studenty zajímavou, dokazuje výmluvně 360 konkretizujících odpovědí. Odpovědi zde nebyly nabízeny v předem daných variantách, studenti a 11 dívek. 
doplňovali vlastní komentáře ke kladům i záporům. Každá zmíněná podrobnost tedy vypovídá o důležitosti pro konkrétní osobnost studenta.

Zde o mnoho více než jinde je zajímavé podívat se na tato data $\mathrm{z}$ hlediska kvantitativního hodnocení, i když je nutné podotknout, že verze nabídnutých variant s možností ke každé se vyjádřit by bývala přinesla vyšší procentuální zastoupení pro jednotlivé položky, nedala by ovšem studentům šanci pojmenovat konkrétně své vlastní zážitky (na uvedené varianty lze tedy nahlížet jako na portfolio, ze kterého je možné podobně stavěnou otázku zkonstruovat pro účely hlubšího zkoumání některých jevů v případě navazujících výzkumů).

Jednoznačně nejčastější odpovědí mezi kladnými položkami byla zkušenost jako taková a zážitek nové zkušenosti $(33 \%)^{7}$, u záporných položek stres $(14 \%)$, tréma, strach a nejistota $(10 \%)$.

Další významněji uvedené odpovědi přináší následující přehled:

\begin{tabular}{|c|c|}
\hline+ & - \\
\hline Poslech ostatních / seznámení se s konkurencí 16 \% & V ničem $13 \%$ \\
\hline Práce s trémou / zbavení trémy 14 \% & Neobjektivní hodnocení poroty 7 \% \\
\hline Motivace $\mathrm{k}$ dalším výkonům 14 \% & Méně času na další aktivity $2 \%$ \\
\hline Vystupování před lidmi 7 \% & Př́lišná absence ve škole 2 \% \\
\hline Noví lidé 7 \% & Zklamání 2 \% \\
\hline Posun dál $5 \%$ & Př́lišná rivalita $2 \%$ \\
\hline Radost z ocenění 4 \% & Srovnání s ostatními, pocit, že jsem horší 2 \% \\
\hline Více cvičení / intenzivnější príprava 4 \% & Vztahy mezi konkurencí, nepř́ijemná atmosféra $2 \%$ \\
\hline \multicolumn{2}{|l|}{ Zjištění, jak na tom jsem 4 \% } \\
\hline \multicolumn{2}{|l|}{ Učit se probojovat sám sebe / sebevědomí 3 \% } \\
\hline \multicolumn{2}{|l|}{ Zdokonalení jevištní / pódiové prezentace $3 \%$} \\
\hline \multicolumn{2}{|l|}{ Záźzitek úspěchu 3 \% } \\
\hline Seznámení se se soutěžním prostředím 3 \% & \\
\hline
\end{tabular}

Tab. 6. Klady a zápory sólové soutěžní praxe před nástupem na střední školu.

Jednoznačně lze sledovat převahu pozitivních jevů nad negativními, což souvisí nejen $\mathrm{s}$ tím, že právě pozdějším studentům hudebního oboru tento systém prověřování rozvoje interpretačních schopností nejlépe svědčí a kvůli nim je stále podporován ve stávající formě, ale i s větším časovým odstupem od doby, kdy se studenti soutěží účastnili. ${ }^{8}$ Hodnocení zastoupená v méně než $2 \%$ uved'me ještě ve výčtu:

Klady - možnost ukázat svůj výkon/talent před porotou, odměna/cena/výhra, zážitky, soutěž jako zábava, obehrání skladeb, širší repertoár, nastudování skla-

7 Data byla zaokrouhlována na celá procenta.

8 O tomto jevu mluví i Josef Alan, když ve své práci Etapy života očima sociologie (Alan 1989) konstatuje zkreslenost výpovědí, konkrétně eliminaci negativních zážitků v závislosti na časovém odstupu od prožité zkušenosti a vnímání faktů v závislosti na konečném hodnocení jevu, kterým $\mathrm{v}$ případě studentů konzervatoře je prozatím happyend $\mathrm{v}$ podobě úspěšných prijijímacích zkoušek na školu. 
deb více do hloubky, naučení hry zpaměti, rychlé čtení nových věcí, samostatnost cvičení/disciplína/učení z chyb, vyslechnutí názorů jiných, poznání jiné výuky a jiných talentů, potkání velké osobnosti/budoucího pedagoga, otestování psychiky, odhalování vlastních možností, dobrý pocit, učení se prohrávat, setkání s lidmi se stejnými zájmy/přátelské přijetí/kolektiv, prohlídka měst/cestování.

Zápory - cvičení stále stejného repertoáru, snížené sebevědomí, zdraví/únava, kritika/způsob hodnocení/bodování, větší nátlak/psychické vytížení, dlouhé cestování, ztráta kamarádů v hlavním oboru, noví neprátelé, negativní zkušenost, nedocenění soutěžní zkušenosti, vysoké požadavky na úkor kvality výkonu, soutěže jsou o kontaktech, zkušenost ze soutěže jako důvod k přerušení studia, finanční náročnost, nucení do soutěžení/nejsem soutěžní typ, nespokojenost z vlastních výkonů, stres z pedagoga, nenávidění vlastního nástroje, perfekcionismus, závist, odtažení od ostatních studovaných nástrojů.

\section{Vyhodnocení dat studentů hudebních gymnázií}

Studenti hudebního gymnázia vykazují účast na soutěžích v době před nástupem na střední školu jen nepatrně nižší než studenti konzervatoře. Data ukazují, že šlo o 79,8 \% studentů zahrnutých do tohoto vzorku. Na rozdíl od konzervatoře zde bylo vyšší zastoupení ve skupině dívek (82,7 \%) než u chlapců (75 \%). Poněvadž řada oborů začala být studována teprve při nástupu ke studiu hudebního gymnázia, což souvisí s nižším věkem dětí v př́ípadě formy osmiletého gymnázia ${ }^{9}$, uved’me v porovnání pouze čtyři nejpočetnější - klavír 81,8 \%, zpěv 90,9 \%, housle $90,5 \%$ a kytaru $71,4 \%$.

V konfrontaci s výsledky konzervatoře (klavír $95 \%$, zpěv 89,4 \% housle $95 \%$ a kytara 68,8 \%) vidíme výraznější rozdíl jen u klavíristů. Vzhledem k tomu, že př́ípad navštěvování soutěží nikoli v začátečnickém, ale teprve $\mathrm{v}$ pozdnějším věku je méně pravděpodobný, lze daný rozdíl vysvětlit snad jen hypotetickým předpokladem, že hráči studující klavír teprve po přechodu z oboru keyboard v dětském věku soutěžili právě na předcházející nástroj.

Z pohledu typu rodiny lze říci, že podoba tř́ stupňů odstupňování podle úrovně hudebního vzdělání sledovatelná ve vzorku konzervatoře je zde narušena zastoupením studentů z rodin obou rodičů hrajících na nástroj v pouhých $68,8 \%$. $\mathrm{V}$ kategoriích otec a oba rodiče v profesi však tentokrát dosahují hodnoty účasti na soutěžích dokonce $100 \%$ prrípadů.

Četnost účasti v soutěžích před nástupem na střední školu je v případě studentů hudebních gymnázií velmi vysoká. Celých 39,8 \% uvedlo, že absolvovali soutěže i několikrát ročně, frekvence zhruba jedenkrát za rok byla zastoupena v $28 \%$

9 Vzorek hudebního gymnázia zahrnoval studenty čtyřletého Hudebního gymnázia Ostrava fungujícího při Konzervatoři Ostrava a studenty Gymnázia a hudební školy hlavního města Prahy, v němž oslovoval studující všech osmi ročníků hudebního gymnázia. Tyto dvě školy byly vybrány záměrně $\mathrm{z}$ důvodu vysoké úrovně ve výuce instrumentálních oborů - řada jejich studentů úspěšně pokračuje ve studiu na vysokých hudebních školách. 
soutěžících studentů a méně často než jednou ročně v 32,3 \%. Největší převahu prezentují data dívek v kategorii několikrát ročně, oproti $34,3 \%$ chlapců zde dosahují hodnoty $42,6 \%$.

Extrém účasti na soutěžích několikrát ročně uváděli nejčastěji studenti oborů zpěv (70 \%), violoncello (66,7 \%), klavír (50 \%) a kytara (50 \%), z nepatrně početně zastoupených oborů ještě akordeon a muzikálový zpěv (oba $50 \%$ ). Houslisté byli v této kategorii zastoupeni jen z jedné čtvrtiny (26,3\%), ovšem výrazná část $\mathrm{z}$ nich vykazovala poté velmi vysoký počet $\mathrm{v}$ kategorii soutěží jedenkrát ročně $(47,4$ \%). Důležité je ještě zmínit obory, u kterých převažuje tendence velmi četné účasti na soutěžích, tedy shrnutí výsledků kategorie Několikrát ročně a Jednou za rok. Sem patřil ve výsledcích hudebních gymnázií především obor violoncello, v němž žádný ze studenti̊, který se soutěží před dobou nástupu na střední školu účastnil, neuvedl soutěžní účast méně často než jedenkrát za rok a zpěv, v němž hodnota dosahovala $90 \%$ prrípadů.

Vzhledem k nízkému početnímu zastoupení, lze o oborech dechových nástrojů shrnout jen tyto poznatky: obor příčná flétna a hoboj byl rovnoměrně zastoupen ve všech třech kategoriích, klarinet, stejně jako trombon, spadal ve $100 \%$ př́padů do kategorie soutěžní frekvence Méně často (než $1 \times$ ročně). Jednou ročně byla také nejzastoupenější kategorií $\mathrm{v}$ oboru lesní roh (tedy představuje nejčetnější případ zapojení v soutěžích ze všech žest’ových oborů).

Dále se ukázalo, že obor klavír, který zde vykazoval nižší zapojení v soutěžích než u studentů konzervatoří, má rovněž méně četnou frekvenci u těch, kteří soutěže navštěvovali. To je zřetelné z počtu 38,4 \% klavíristů, kteří uvedli účast v soutěžích méně často než jedenkrát ročně. (Ve skupině houslistů je pak pro zajímavost tato kategorie zastoupena pouze v $26,3 \%$.)

Po porovnání dat jednotlivých kategorií rodin lze říci, že v rodinách profesních hudebníků šlo sice o nejvyšší počet zastoupení studentů v otázce účasti v soutěžích, avšak nejčetnější je účast méně než jedenkrát $\mathrm{v}$ roce. Matky $\mathrm{v}$ profesi, $\mathrm{v}$ př́ípadě jejichž dětí, jak už bylo řečeno, nebyla zaznamenána účast na soutěžích ve $100 \%$ prŕpadů, naopak vykazují daleko častěji účast svých dětí s frekvencí jedenkrát v roce.

Podobnou a ještě silnější tendenci lze spatřit $\mathrm{v}$ rodinách obou rodičů hrajících na nástroj. $\mathrm{V}$ tomto typu rodiny byla hodnota účasti v soutěžích nižší než ve všech ostatních kategoriích, nyní však vidíme, že ve frekvenci účasti tvoří největší zastoupení (54,5 \% dětí navštěvuje soutěže častěji než jedenkrát za rok). Vysoké zastoupení v kategorii nejvyšší četnosti soutěží vykazují také rodiny „rodičů bez nástroje“. Vzhledem k tomu, že o otázkách účasti v soutěžích rozhodují pedagogové, lze předpokládat, že v rodinách rodičů v profesi probíhá určitá korekce nároků, kterou ve vztahu k pedagogům rodiče uplatňují.

Jako impuls pro účast na soutěžích uváděli studenti v $62 \%$ rozhodnutí pedagoga, v dalších 9,8 \% rozhodnutí své a pedagoga. Velmi nízký vliv byl připisován rodičům (pouze jejich vliv $1,1 \%$, vliv rodičů a pedagoga $2,2 \%$, zajímavé rovněž je, že ve všech těchto prrípadech se jednalo o dívky), rozhodnutí studenta samotného bylo naopak variantou velmi výraznou (19,6\% samostatného rozhodnutí, 5,4 \% společného rozhodování s rodiči a pedagogem). 
Zajímavé výsledky prrináší průnik kategoriemi Četnost účasti $v$ soutěžich a Vliv na rozhodnutí. Ukazuje se, že u studentủ účastnících se soutěží častěji vzrůstá uváděný počet těch, kteří se pro tuto variantu rozhodli sami (rozdíl $22 \%$ ku 44 \%) nebo spolu s pedagogem (rozdíl 11,1 \% a 77,8 \%), a tím se jeví jako oslabená kategorie rozhodnutí pedagoga. Zda je impulzem k vyšší účasti právě přebírání zodpovědnosti ze strany studenta, či je tato zodpovědnost vyšší účastí vyvolávána motivací okolí, nelze na tomto místě bez doplňujících výzkumů určit.

K pouze vlastnímu rozhodnutí se častěji hlásili chlapci, u dívek byla častější verze spolurozhodování s pedagogem. V konečném výsledku však všechny varianty, které vycházely také z popudu studenta, jsou u obou pohlaví téměř totožné (o $0,6 \%$ silnější zastoupení u dívek).

Velmi neočekávané výsledky přineslo vyhodnocení průniku se studovanými obory. Ukázalo velmi široké spektrum oborů, ve kterých přicházely impulzy k účasti na soutěžích výhradně ze strany pedagoga. Šlo o obory příčná flétna, klarinet, trubka, trombon, kytara, cimbál, viola a violoncello. Ani v jediném prŕípadě studenti těchto oborů neuvedli podíl kohokoli jiného včetně sebe na rozhodování o účasti v soutěžích.

Z pohledu rozdílných př́istupů $\mathrm{v}$ různých typech hudebního zázemí v rodinách je nutné zdůraznit dva výrazné jevy, $90 \%$ podílu rozhodování pouze pedagogů u studentů pocházejících ze zázemí rodin otců hrajících na nástroj a naopak $75 \%$ zastoupení rozhodnutí ze strany studentů z rodin obou rodičů v profesi.

Vnímání náročnosti soutěžního provozu vyjádřili studenti opět vcelku jednoznačně. 87,6 \% považuje nároky soutěží za přiměřené, 7,8 \% za zanedbatelné nebo spíše zanedbatelné (zahrnuto je i 1,1 \% př́ípadů kombinace zanedbatelné a přiměřené) a jen 4,5 \% za př́liš zatěžující (opět včetně $1,1 \%$ zastoupení kombinace skupin přiměřené a př́liš zatěžující, volili zástupci trubky, klavíru a zpěvu). Zmínit je třeba zastoupení obou krajních hodnot shodně u oborů klavír a zpěv. Tyto hodnoty vykazovaly rovněž vyšší poměr ve skupině chlapců (přímo variantu príliš zatěžující vybralo $6,5 \%$ chlapců účastnících se soutěží, mezi dívkami jen $1,7 \%)$.

\section{Závěrem}

Ačkoli se ukázalo, že soutěže $\mathrm{v}$ dnešní podobě vesměs vyhovují těm, kdo se později dostávají na střední hudební školy, a že i s pojmenovanými zápory tito studenti jejich nároky neshledávají zpětně jako př́liš zatěžující, není od věci zmínit se o alternativních cestách, které by přesto mohly i tyto, ale především pak ostatní děti zabývající se hudbou rozvíjet jinak, a v prŕpadě realizace formou konkrétních projektů managmentu v kultuře obohatit spektrum nabídky kulturního vyžití dětí.

1. Otázka jiných forem hodnocení umístění. V praxi se hodnocení soutěží ZUŠ dostalo do stádia, kdy je často jednou cenou ohodnoceno více žáků/souborů (např. 2 první místa, 3 druhá atd.). Dochází tím k paradoxu, že dítě na pozici 
3. místa $\mathrm{v}$ soutěži mohlo být $\mathrm{v}$ celkovém bodovém ohodnocení třeba i celkově páté a horší. Takové hodnocení pak odpovídá spíše zařazení do pásem, které některé ze soutěží či přehlídek začaly z tohoto důvodu oficiálně používat (zlaté pásmo, stř́brné pásmo atd.). ${ }^{10}$

Snaha vyhnout se poměřování dětí a umožnit jim pouze si poslechnout navzájem své výkony, byla zaznamenána např. $\mathrm{v}$ př́ípadě mezinárodní houslové soutěžní přehlídky Nové evropské talenty v Českých Budějovicích. Bohužel požadavek ZUŠ po konkrétním ohodnocení žáka, aby mu mohlo být školou proplaceno startovné, byl natolik silný, že se od této praxe muselo upustit. Je tedy otázkou, nakolik by bylo nahraditelné současné pojetí ještě radikálnějším př́stupem pouhé zpětné vazby ve formě konkrétních doporučení od poroty, jaké funguje např̀. $\mathrm{v}$ praxi některých soutěžních přehlídek amatérských sborů.

2. Otázka dalších podob soutěžního zaměření. Z výsledků zpětných vazeb studentů středních hudebních škol se ukázalo, že drtivá většina studentů hodnotí soutěže převážně z pohledu dalšího vývoje své techniky, repertoáru a tedy schopnosti provést dokonale zadané nastudované skladby. Podle mého názoru by však měla přijít otázka, zda se omylem toto snažení o fixování určité interpretace notového zápisu nestává či už nestalo jediným cílem nejen soutěžního poměřování, ale i podstatou studia na hudebně vzdělávacích školách?

Pouze v jediném př́padě se ve zpětné vazbě objevil tento názor - hudba neni soutěž. Lze jím upozornit na několik různých faktů: a) problematiku hodnocení hudebního výkonu pomocí více či méně objektivních hledisek - kritika objektivnosti porot se ostatně dostala velmi často mezi jmenované negativní stránky fungování soutěží, b) fakt, že hudební výkon by měl být ve službě hudebního díla - tomu v mnoha soutěžích napomáhají speciálně udělované ceny za interpretaci konkrétního díla, za mimořádný výkon korepetitora ap., ale prŕmo netvoří základní požadavek hodnocení výkonu, c) nepřímo poukazuje i na jev užívání tzv. soutěžního repertoáru, který je specifický a nemusí vždy korespondovat s kvalitou skladeb, se kterými by bylo vhodné nechat konfrontovat nejen budoucí profesionální interprety.

(Odkazuji tím namátkou na některé skladby houslového repertoáru, které se pyšní technickou náročností, ale co do hudební kvality nabízejí začínajícím interpretům díla velmi pochybné hodnoty, či verze některých skladeb, u nichž nedosahuje doprovodná složka klavírního partu, což je dané dobou jejího vypracování, na standardy dnešních poznatků provádění generálbasové praxe apod.)

Vrat'me se ale k otázce položené výše, protože souvisí s původní hrdostí našeho národa na nadnesené rčení „co Čech, to muzikant". Toto rčení však nesouviselo se schopností českých hudebníků interpretovat koncertní skladby, jako spíše se schopností projevovat se v nástroji s nebývalou muzikalitou a také s flexibilitou jeho užívání.

10 Př́ikladem je soutěžní přehlídka Mládí a Bohuslav Martinů pořádaná ZUŠ v Poličce. [online] [cit. 2015-11-01] Dostupné z: <http://http://www.zusbmpolicka.cz/mladi-a-bohuslav-marti$\mathrm{nu}>$. 
Nenechme se mýlit, ale schopnost přidat se $\mathrm{s}$ nástrojem $\mathrm{k}$ písničce zpívané u táboráku, at ji začne zpěvák od kteréhokoli tónu, tedy transponovat ji do kterékoli tóniny, zahrát oslavencovi „z placu“ jednoduchou fanfáru, připojit se k melodii druhým hlasem či akordickým doprovodem nebo improvizovat vkusnou předehru, mezihru či dohru lidové písničce, jsou dovednosti, které získávají punc hudebnosti i dnes. Pokud však žák hudební školy potřebuje mít ke každé hudbě noty, naznačuje to, že žije v zajetí interpretačních požadavků na úkor těch muzikantských. Na místo porozumění hudebnímu jazyku vítězí provedení zapsané hudby. Na takové vnímání upozorňovaly nepř́mo i odkazy negativního hodnocení studentů konzervatoře, kteř́ zmiňovali jako problém při studování soutěžního repertoáru „zanedbávání látky roku“ (pokud tím ovšem měli na mysli pouze vypouštění etud během hodin hlavního oboru, je ve skutečnosti ještě hůře).

A nejde jen o jevy spjaté s nástrojem, na který se učí. Většina dětí má dnes problémy to, co dokáží zahrát z not na nástroj bez př́ipravy, z týchž not zazpívat. Hlavička noty začíná představovat určitou klávesu, určité místo na hmatníku zahrané určitým prstem, určitou hmatovou kombinaci na dechových nástrojích a již neznamená přesnou výškovou představu a hlasovou zkušenost. Tady si lze jen povzdechnout nad tím, že se u nás výchova solmizací a fonogestikou dostala na okraj zájmu nejen základních, ale i hudebních škol.

Proto tedy $\mathrm{k}$ závěru patř́i podle mého soudu apel na projekty stavěné i jinak. Proč napřn. neuvažovat o možnosti hudební „olympiády“, v níž by šlo právě o některou z výše jmenovaných dovedností, o možnosti hudebního víceboje zaměřeného i na hru z listu, okamžité nastudování skladby, improvizaci, transpozici, hru $\mathrm{s}$ barevností zvuku (varianty interpretace) atp. Nebo jen pro začátek soutěž pro děti hrající na více nástrojů, v níž by mohly v každém kole kombinovat vystoupení několika z nich... Každý projekt takového typu by nepochybně vhodně doplnil škálu př́iležitostí mladých hudebníků postoupit ve svém hudebním snažení dále.

Marie Novotná (novotna.czech@seznam.cz), Ústav hudební vědy, Filozofická fakulta, Masarykova univerzita, Brno, CZ.

\section{ABSTRACT \\ SOME SPECIFICS IN THE PERCEPTION OF MUSICAL COMPETITI- ONS FROM THE VIEWPOINT OF STUDENTS OF PRIMARY AND SECONDARY MUSIC SCHOOLS}

This study focuses on competitions in musical interpretation and examines these competitions from viewpoint of pupils and students of primary and secondary music schools. The study is based on empirical quantitative research conducted in 2014 and presented in the $\mathrm{Ph} . \mathrm{D}$. thesis entitled „The progress of a preparation for the musician career and a career motivation from the perspective of the art school pupils and students" and is looking for alternative approaches concerning the growth of the musical potential of gifted children. It shows that the conventual perception of competitions still satisfies mainly future professional musicians who consider its level of difficulty as suitable. 


\section{Key words}

musical competition, primary art school, conservatoire, musical high/grammar school, musical education, musical sociology, musicality, professional preparation, career of a musician, development of musical talent

\section{Bibliography}

ALAN, Josef. Etapy života očima sociologie. 1. vyd. Praha: Panorama, 1989.

ELLIOT, Philip. The Sociology of the Professions. 1. vyd. London and Basingstoke: The Macmillan Press LTD, 1972.

HAVLOVÁ, Jitka. Profesni dráha ve 20. století: Úvod do sociologie povolání. 1. vyd. Praha: Univerzita Karlova-Karolinum, 1996.

JAKUBEKOVÁ, Ivana. Osobnost hudebniků. Diplomová práce. FF MU Brno, 2005.

KINGSBURY, Henry. Music, Talent, and Performance: A conservatory cultural systém. Philadelphia: Temple University Press, 1988.

KOLOFÍKOVÁ, Klára. Faktory sociálniho prostředi ovlivňujici volbu umělecké profese: Analýza subjektivnich výpovédi mladých hudebnikư. Bakalářská práce. FSS MU Brno, 2002.

NETTL, Bruno. Heartland Excursions: Ethnomusicological Reflections on School of Music. 1. vyd. Urbana and Chicago: University of Illinois Press, 1995.

Organizační rád soutěži a přehlídek ZUŠ. Manuál hodnocení [online]. [Cit. 2015-11-01]. Dostupné z: <http://www.uur-zuscr.cz/dokumenty/organizacni-rad>.

Ministerstvo školství, mládeže a tělovýchovy: Základní umělecké vzdělávání [online]. [Cit. 201511-01]. Dostupné z: <http://www.msmt.cz/vzdelavani/zakladni-vzdelavani/zakladni-umelecke-vzdelavani>.

Vyhláška č. 71/2005 Sb., o základním uměleckém vzdělávání. In: Zákony V/2009: Sborník úplných znění zákonů pro státní správu, veřejnou správu a školství. Český Těšín: Poradce, 2009. 